\title{
PROSPEK PENGEMBANGAN USAHA TERNAK SAPI POTONG DI KECAMATAN BOLANGITANG TIMUR KABUPATEN BOLAANG MONGONDOW UTARA
}

\author{
Moh. Andri Otoluwa*, A. H. S. Salendu, A. K. Rintjap, M.T. Massie \\ Fakultas Peternakan Universitas Sam Ratulangi Manado, 95115
}

\begin{abstract}
ABSTRAK
Penelitian inibertujuan untuk menganalisispotensi sumberdaya Kecamatan Bolangitang Timur Kabupaten Bolaang Mongondow Utara dalam pengembangan usaha ternak sapi potong.Penelitianmenggunakan metode survey dengan menggunakan daftar pertanyaan (kuesioner) sebagai alat pengumpulan data. Sumber data yang diambil meliputi data primer dan data sekunder. Pengumpulan data dilakukan pada bulan Juni sampai Juli 2015. Analisis yang digunakan ialah analisisdeskriptif, analisis daya dukung lahan (PMSL), dan analisis SWOT. Hasil penelitian menunjukan bahwa Analisis menunjukan bahwa potensi maksimum dalam satuan ternak berdasarkan sumberdaya lahan kering, padang rumput, dan lahan rawa (PMSL) sebesar 8.879 ST. Angka ini menunjukan bahwa wilayah Kecamatan Bolangitang Timur potensial untuk pengembangan ternak sapi.
\end{abstract}

Kata Kunci : Sapi Potong, prospek, Pengembangan Usaha

\section{ABSTRACT}

\section{THE PROSPECT OF BEEF CATLE INDUSTRY DEVELOPMENT IN EAST BOLANGITANG DISTRICT, NORTH BOLAANG MONGONDOW REGENCY}

The purpose of this research was to find out the potential resources on beef cattle industry development in East Bolangitang

*Korespondensi (correspondence)

Email : otolua_andri@yahoo.co.id district, North Bolaang Mongondow regency. Survey method (questionnaire) was used in order to get primary and secondary data, from June until July, 2015. All the data taken were then analyzed using SWOT and Land Carrying Capacity analysis, as well as descriptive analysis. It was found in this research that, the maximum potency of livestock units based on dry land, savannah and swampland (wetland) resources amounted to $8.879 \mathrm{ST}$ (Satuan Ternak). This number depicted that the district of East Bolangitang potential to develop cattle industry

Keywords: Cattle, prospects, Business Development

\section{PENDAHULUAN}

Pembangunan peternakan dihadapkan pada sejumlah tantangan baik dari lingkungan dalam negeri maupun dari lingkungan global. Dinamika lingkungan dalam negeri berkaitan dengan dinamika permintaan produk peternakan, penyediaan bibit ternak, kualitas bibit, terjadinya berbagai wabah penyakit ternak yang sangat merugikan, serta tuntutan perubahan manajemen pembangunan sejalan dengan pelaksanaan otonomi daerah dan partisipasi masyarakat. 
Sedangkan isu global yang sedang dihadapi adalah perubahan iklim global, krisis pangan dan energi, harga pangan serta energi meningkat.Dari sisi pembangunan ekonomi, bukti empiris menunjukan bahwa sub sektor peternakan memiliki peran cukup strategis utamanya dari kontribusi terhadap produk domestik bruto, penyerapan tenaga kerja, penyedia bahan pangan, bahan energi, pakan dan bahan baku industri, serta sumber pendapatan dipedesaan. Namun besarnya peran tersebut, ternyata belum dinikmati oleh para pelaku usaha peternakan utamanya masyarakat peternak sendiri. Pembangunan peternakan sebagai bagian integral pembangunan pertanian yang merupakan bagian dari pembangunan nasional bertujuan antara lain untuk meningkatkan pendapatan dan kesejahtraan peternak, tersedianya kesempatan kerja dan berusaha, tercapainya keseimbangan antara pemanfaatan dan pelestarian sumberdaya alam dan genetik ternak.

Menurut Roessali et al (2005). budi daya sapi potong dengan tujuan untuk menghasilkan daging dan berorientasi pasar masih rendah. Kedua, pada sentra produksi sapi di kawasan timur Indonesiadengan porsi $16 \%$ dari populasi nasional, serta memiliki padang penggembalaan yang luas, pada musim kemarau panjang sapi menjadi kurus, tingkat mortalitastinggi, dan angka kelahiran rendah. Kendala lainnya adalah berkurangnya areal penggembalaan, kualitas sumber daya rendah, akses ke lembaga permodalan sulit, dan penggunaan teknologi rendah (Syamsu et al. 2003; Isbandi 2004; Ayuni 2005; Rosida 2006). Faktor pendorong pengembangan sapi potong adalah permintaan pasar terhadap daging sapi makin meningkat, ketersediaan tenaga kerja besar, adanya kebijakan pemerintah yang mendukung upaya pengembangan sapi potong, hijauan pakan dan limbah pertanian tersedia sepanjang tahun, dan usaha peternakan sapi lokal tidak terpengaruh oleh krisis ekonomi global (Kariyasa 2005; Gordeyase et al. 2006; Rosida 2006; Utomo 2004).

Kabupaten Bolaang Mongondow Utara merupakan salah satu kabupaten di Sulawesi Utara yang mempunyai potensi sangat besar dalam mengembangkan usaha ternak sapi potong tapi belum dimanfaatkan oleh masyarakat. Ini ditandai dengan belum menjadi usaha produktif, masih tradisional dan skala kecil. Usaha peternakan sapi potong di wilayah Kabupaten Bolaang Mongondow Utara khususnya kecamatan Bolangitang Timur, semestinya dapat dikembangkan oleh petani peternak dengan memanfaatkan faktor-faktor penunjang berupa pelabuhan, 
poskeswan, RPH. dan berpedoman pada potensi sumberdaya wilayah yang bersifat internal dan eksternal. Kecamatan Bolangitang Timur Kabupaten Bolaang Mongondow Utara memiliki sumberdaya tanaman pangan dan hortikultura yang dikembangkan. sebagai berikut:

- Padi sawah luas panen 353 ha dan ratarata produksi 1876 ton

- Padi ladang luas panen 352 ha dan ratarata produkpsi 1163 ton

- Jagung luas panen 474 ha dan rata-rata produksi 2242 ton

- Perkebunan kelapa luas tanam 3508,00 ha rata-rata produksi 3193,71 ton (Sumber Dinas Pertanian Peternakan Perkebunan dan Kehutanan Bolmut 2013).

Berdasarkan hal tersebut diatas maka dirasa perlu untuk mengadakan suatu penelitian terhadap daya dukung sumberdaya yang dimiliki wilayah dalam rangka penentuan alternatif strategi pengembangan usaha ternak sapi potong.

\section{METODE PENELITIAN}

Pengumpulan data menggunakan metode survei. Survei adalah suatu proses pengumpulan informasi dari responden pada suatu populasi dengan harapan akan diperoleh data yang akurat dengan mmenggunakan daftar pertanyaan (kuesioner) sebagai alat pengumpulan data (Sigarimbun dan Effendi, 1999). Sumber data yang digunakan dalam penelitian ini adalah data primer dan sekunder,dimana data primer diperoleh langsung dari wawancara dengan responden (peternak) yang berada di beberapa desa di Kecamatan Bolangitang Timur. Yang akan digunakan sebagai informasi (data) untuk mengetahui sumberdaya, potensi, dan kendala ditingkat peternak dalam upaya pengembangan sapi potong. Datasekunderdiperolehdarilembaga atau instansi yang terkait antara lain kantor Dinas Pertanian Peternakan Perkebunan dan Kehutanan, Badan Pusat Statistik dan Kantor Kecamatan Bolangitang Timur Informasi lainnya diperoleh melalui Publikasi, Jurnal-jurnal penelitian yang telah ada baik melalui perpustakaan ataupun internet.

\section{HASIL DAN PEMBAHASAN}

Sumberdaya alam mempunyai peranan penting dalam pembangunan pertanian dan pembangunan ekonomi. Kemajuan suatu wilayah tergantung pada potensi sumberdaya alam yang memiliki dan kemampuan sumberdaya manuasia yang mengelolanya

Hasil kajian lapangan dapat dijelaskan menjelaskan Sumberdaya lahan. Luas wilayah kecamatan Bolangitang Timur 44.564 ha $\left(445,64 \quad \mathrm{~km}^{2}\right) \quad$ yang 
diklasifikasikan menurut ekosistem dan penggunaannya sebagai berikut : tegal 4.260 ha,ladang 14.655 ha, perkebunan 3.890 ha, ditanami pohon/hutan rakyat 525 ha, lahan tidur atau tidak diusahakan 1.310 dan pemukiman mencakupi perkantoran, sungai, jalan raya 18.930 ha, dan tabel 2 menunjukan tanaman pangan jagung memiliki luas panen tertinggi yakni 474 Ha dengan produksi 2.242 ton/tahun dan kacang tanah memiliki luas panen terendah yakni $1 \mathrm{Ha}$ dengan produksi 2 ton/tahun.

Jumlah penduduk di Kecamatan Bolangitang Timur pada tahun 2015 adalah 14.276 jiwa yang terdiri dari pria 7.402 jiwa dan wanita 6.874 jiwa yang mencakup 4.527 kk (Kantor Kecamatan Bolangitang Timur). Potensi penunjang yaitu adalah kemampuan atau keadaan yang dapat mendukung suatu kegiatan (usaha) dan biasanya erat kaitannya dengan sumberdaya. Di kecamatan Bolangitang Timur terdapat satu rumah potong hewan (RPH), yang digunakan untuk pemotongan ternak. Ketersedian RPH di Kecamatan Bolangitang Timur merupakan salah satu langkah maju untuk mengerakkan bidang agribisnis peternakan. Selain RPH terdapat PUSKESWAN (pusat kesehatan hewan) yang berlokasih di Kecamatan Bolangitang Barat yang menjadi lokasi untuk memeriksa dan mengkarantinakan ternak sakit dan disangka sakit yang berjarak tidak jauh dari Kecamatan Bolangitang Timur, Beternak sapi sudah lama dikenal masyarakat di Kecamatan Bolangitang Timur dimana sistem pemeliharaannya masih bersifat tradisional. Jumlah ternak yang dimiliki peternak bervariasi 3-6 ekor. Tujuan pemeliharaan adalah sebagai usaha pokok dan sebagai tabungan untuk membiayai studi anak-anak.Berdasarkan hasil analisis SWOT bahwa di wilayah penelitian menunjukan faktor-faktor strategis pendorong pengembangan ternak sapi potong ialah ketersediaan lahan, ketersediaan air, adanya ternak sapi, ketersediaan sumberdaya manusia (tenaga kerja), iklim kondusif untuk investasi, dan prospek pasar dan aksessibilitas. Faktor strategis sebagai penghambat yaitu modal, pemotongan betina produktif, munculnya penyakit dan inbridingHasil analisis potensi maksimum sumberdaya lahan di Kecamatan Bolangitang Timur menunjukan potensi maksimum sumberdaya lahan kering, padang rumput, dan lahan rawa adalah sebesar 8.879 ST. Artinya berdasarkan sumberdaya lahan di Kecamatan Bolangitang Timur masih dapat menampung populasi ternak sapi sebesar nilai PMSL (8.879 ST). 
Tabel 1. Distribusi Lahan Menurut Penggunaanya di Kecamatan Bolangitang Timur

\begin{tabular}{clcc}
\hline No & \multicolumn{1}{c}{ Lahan Menurut Penggunaanya } & Luas (Ha) & Presentase (\%) \\
\hline 1 & Tegal & 4.260 & 9,55 \\
2 & Ladang & 14.655 & 32,88 \\
3 & Perkebunan & 3.890 & 8,72 \\
4 & Hutan & 525 & 1,17 \\
5 & Lahan Tidur & 1.310 & 2,93 \\
& Pemukiman, Perkantoran, Sungai dan Jalan & & \\
6 & raya & 18.930 & 42,47 \\
\hline & Jumlah & 44.564 & 100 \\
\hline
\end{tabular}

Dinas Pertanian Peternakan Perkebunan dan Kehutanan Bolmut 2015

Tabel 2 JenisTanamanPangan yang Dikembangkan.

\begin{tabular}{clcc}
\hline No & Tanaman Pangan & Luas Panen (Ha) & Produksi (Ton) \\
\hline 1 & Padi sawah & 353 & 1.876 \\
2 & Padi ladang & 352 & 1.163 \\
3 & Jagung & 474 & 2.242 \\
4 & Kacang tanah & 1 & 2 \\
5 & Kacang hijau & 4 & 7 \\
6 & Ubi kayu & 12 & 26 \\
7 & Ubi jalar & 9 & 20 \\
8 & Sayur-sayuran & 279 & 17.541 \\
\hline
\end{tabular}

Dinas Pertanian Peternakan Perkebunan dan Kehutanan Bolmut 2015

Tabel 3. Keadaan Umur, Tingkat Pendidikan, Pengalaman dan Jumlah Anggota Keluarga Petani Peternak Responden.

\begin{tabular}{|c|l|c|}
\hline No & \multicolumn{1}{|c|}{ Uraian } & Jumlah (orang) \\
\hline A. & Kelompok Umur & 4 \\
1. & $30-55$ tahun & 1 \\
2. & $>56$ tahun & \\
B. & Tingkat Pendidikan & 3 \\
1. & SD & 2 \\
2. & SMP/SLTP & \\
3. & SLTA & 5 \\
4. & Tidak sekolah & \\
C. & Pengalaman Beternak & \\
1. & 5-15 tahun & \\
2. & 16-30 tahun & 5 \\
3. & $>30$ tahun & \\
D. & Jumlah Anggota Keluarga & \\
1. & $3-6$ & \\
2. & $7-10$ & \\
\hline
\end{tabular}

Data diolah 2015 
Tabel 3 menggambarkan bahwa 4 orang responden tergolong pada usia produktif. Umur sangat mempengaruhi kemampuan fisik peternak dalam mengelola usaha ternak sapi potong dan usaha tani lainnya. Mubyarto (1986) menjelaskan bahwa usia yang tergolong produktif dalam artian mampu melaksanakan usahanya berada antara 1555 tahun, sedangkan menurut Tjiptoherianto (1990), bahwa yang tergolong usia kerja adalah 15-60 tahun. Tingkat pendidikan responden pada tabel 3 menunjukan 3 orang berpendidikan SLTP, 2 orang berpendidikan SLTA. Fandeli (1992) mengatakan pendidikan penduduk desa yang $50 \%$ penduduk tamat SD dikatakan sedang.

\section{Pengalaman peternak dalam} melaksanakan usaha budidaya ternak sapi potong adalah rata-rata sekitar 12 tahun. Soeharsono et al. (2010) mengemukakan bahwa semakin lama pengalaman peternak membudidayakan ternak sapi potong, memungkinkan mereka untuk lebih banyak belajar dari pengalaman, sehingga dapat dengan mudah menerima inovasi teknologi yang berkaitan dengan usaha ternak sapi potong menuju perubahan baik secaraindividu maupun kelompok..

Syamsu (2003) menjelaskan keterbatasan pendidikan dan pengalaman akan menutup cakrawala gagasan yang ada pada memorinya. Tabel 3 menunjukan seluruh responden sudah cukup berpengalaman dalam beternak. Hal ini disebabkan usahatani atau peternak khususnya ternak sapi merupakan usaha pokok bagi petani responden. Jumlah anggota keluarga bervariasi antara 3-6 orang,. Jumlah anggota keluarga mencerminkan tersedianya tenaga kerja dalam usahatani ternak.

Usaha peternakan memerlukanmodal yang besar, terutama untuk pengadaan pakan dan bibit. Biaya yang besar ini sulit dipenuhi oleh peternak pada

umumnya yang memiliki keterbatasan modal (Hadi dan Ilham 2000).

\section{KESIMPULAN}

Berdasarkan hasil penelitian dapat disimpulkan bahwa :

1. Kecamatan Bolangitang Timur mempunyai potensi yang sangat besar dalam meningkatkan populasi ternak sapi dilihat dari sumberdaya lahan yang tersedia, penyedia makanan ternak dan penyediaan tenaga kerja.

2. Analisis menunjukan bahwa potensi maksimum dalam satuan ternak berdasarkan sumberdaya lahan kering, padang rumput, dan lahan rawa (PMSL) sebesar 3.423 ST. Angka ini menunjukan bahwa wilayah Kecamatan Bolangitang 
Timur potensial untuk pengembangan ternaak sapi.

\section{DAFTAR PUSTAKA}

Badan Pusat Statistik SULUT, 2013.

Dinas Pertanian Peternakan Perkebunan dan Kehutanan Bolmut2015.

Gordeyase, I.K.M., R. Hartanto, dan W.D. Pratiwi. 2006. Proyeksi daya dukung pakan limbah tanaman pangan untuk ternak ruminansia di Jawa Tengah. J. Indon. Trop. Anim. Agric. 32(4): 285-292.

Hadi, P.U. dan N. Ilham. 2002. Problem dan prospek pengembangan usaha pembibitan sapi potong di Indonesia. Jurnal Penelitian dan Pengembangan Pertanian 21(4): 148-157.

Kariyasa, K. 2005. Sistem integrasi tanamanternakdalam perspektif reorientasi kebijakan subsidi pupuk dan peningkatan pendapatan petani. Jurnal Analisis Kebijakan Pertanian 3(1): $68-80$.

Mubyarto. 1986 Peluang Kerja dan Berusaha di Pedesaan. Edisi Pertama. Penerbit BPEE, Yogyakarta

Rosida, I. 2006. Analisis Potensi Sumber DayaPeternakan Kabupaten Tasikmalaya sebagai Wilayah Pengembangan Sapi Potong. Skripsi. Fakultas Peternakan Institut Pertanian Bogor.

Roessali, W., B.T. Eddy, dan A. Murthado. 2005.Upaya pengembangan usaha sapi potong melalui entinitas agribisnis “corporate farming"di Kabupaten
Grobogan. Jurnal Sosial Ekonomi Peternakan 1(1): 25-30.

Sigarimbun, Masri. dan Sofyan Effendi, $1999 \mathrm{fv}$ metode penelitian survey. Jakarta. PT pustaka LP3ES.

Soeharsono., R. A. Saptati dan K. Diwyanto.2010. Kinerja Reproduksi Sapi Potong Lokal dan Sapi Persilangan Hasil Inseminasi Buatan di Daerah Istimewa Yogyakarta. Prosiding Seminar Nasional Teknologi Peternakan dan Veteriner. Bogor 3-4 Agustus 2010. Pusat Penelitian dan Pengembangan Peternakan, Bogor. hlm 89-99.

Syamsu, A.J., L.A. Sofyan, K. Mudikdjo, dan G.Said. 2003. Daya dukung limbah pertanian sebagai sumber pakan ternak ruminansia di Indonesia. Wartazoa 13(1): 30-37.Suryana. 2009.Pengembangan Usaha Ternak Sapi Potong Berorientasi Agribisnis dengan Pola Kemitraan. Jurnal Litbang Pertanian, 28(1), hal. 29-37.

Tjiptoherijanto, P.1999. Keseimbangan Penduduk, Manajemen Sumberdaya Manusia dan Pengembangan Daerah. Pustaka Sinar Harapan, Jakarta.

Utomo, B.N. dan E. Widjaja. 2004. Limbah padat pengolahan sawit sebagai sumber nutrisi ternak ruminansia. Jurnal Penelitian dan Pengembangan Pertanian 23(1): 21-28. 
